\title{
Effect of Sequential Applications of Protoporphyrinogen Oxidase-Inhibiting Herbicides on Palmer Amaranth (Amaranthus palmeri) Control and Peanut Response
}

\author{
Benjamin P. Sperry, Jason A. Ferrell, Hunter C. Smith, Venancio J. Fernandez, \\ Ramon G. Leon, and Clyde A. Smith*
}

Two experiments were conducted in 2013 and 2014 in Florida to evaluate the effects of protoporphyrinogen oxidase (PPO)-inhibiting herbicides and single versus sequential applications on Palmer amaranth control and peanut injury. Protoporphyrinogen oxidase-inhibiting herbicides are among the last available herbicides for the POST control of acetolactate synthase (ALS)-resistant Palmer amaranth in peanut. Lactofen $\left(219 \mathrm{~g}_{\text {ai }} \mathrm{ha}^{-1}\right)$ applied $5 \mathrm{~d}$ after the initial application provided the highest level of Palmer amaranth control 7 and $14 \mathrm{~d}$ after initial application (DAIT). Delaying sequential applications of lactofen to $15 \mathrm{~d}$ resulted in the highest level of Palmer amaranth control 21 and 28 DAIT. Similar to Palmer amaranth control, foliar injury to peanut was often highest from lactofen applications, and by 28 DAIT lactofen treatments were the only treatments that caused foliar injury. Although no statistical difference was observed between yields of plots treated with

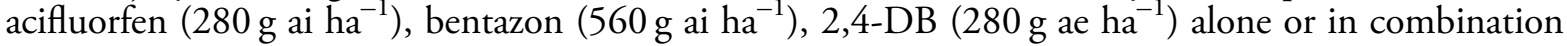
with each other, plots treated with sequential applications of lactofen 5 or 15 DAIT produced the lowest yields. Sequential applications of lactofen applied 15 DAIT controlled Palmer amaranth more effectively than any other treatment but also caused the highest level of peanut injury. The use of sequential applications of lactofen was the most effective method for control of Palmer amaranth in this study, but did reduce peanut yield.

Nomenclature: acifluorfen; bentazon; lactofen; 2,4-DB; Palmer amaranth, Amaranthus palmeri S. Wats.; peanut, Arachis hypogaea L.

Key words: ALS-resistant Palmer amaranth, sequential applications, crop injury.

\begin{abstract}
En 2013 y 2014 se realizaron dos experimentos en Florida para evaluar los efectos de los herbicidas inhibidores de protoporphyrinogen oxidase (PPO) y aplicaciones sencillas versus secuenciales sobre el control de Amaranthus palmeri y el daño al maní. Los herbicidas inhibidores de protoporphyrinogen oxidase están entre los últimos herbicidas disponibles para el control POST de $A$. palmeri resistente a herbicidas inhibidores de acetolactate synthase (ALS) en maní. Lactofen $\left(219 \mathrm{~g}\right.$ ai ha $\left.{ }^{-1}\right)$ aplicado $5 \mathrm{~d}$ después de la aplicación inicial (DAIT) brindó el mayor nivel de control de $A$. palmeri 7 y 14 DAIT. El retrasar las aplicaciones secuenciales de lactofen a $15 \mathrm{~d}$ resultó en el mayor nivel de control de $A$. palmeri 21 a 28 DAIT. Similarmente al control de $A$. palmeri, el daño foliar en el maní fue frecuentemente más alto con aplicaciones de lactofen, y a 28 DAIT los tratamientos con lactofen fueron los únicos que causaron daño foliar. Aunque no se observaron diferencias estadísticas entre los rendimientos de las parcelas tratadas con acifluorfen $\left(280 \mathrm{~g} \mathrm{ai} \mathrm{ha}^{-1}\right)$, bentazon $\left(560 \mathrm{~g}^{\mathrm{ai} \mathrm{ha}} \mathrm{ha}^{-1}\right), 2,4-\mathrm{DB}\left(280 \mathrm{~g} \mathrm{ae} \mathrm{ha}{ }^{-1}\right)$ solos o en combinaciones entre ellos, las parcelas tratadas con aplicaciones secuenciales de lactofen 5 ó 15 DAIT produjeron los menores rendimientos. Las aplicaciones secuenciales de lactofen aplicado 15 DAIT controlaron $A$. palmeri más efectivamente que cualquier otro tratamiento, pero también causaron el mayor nivel de dańo en el maní. El uso de aplicaciones secuenciales de lactofen fue el método más efectivo para controlar $A$. palmeri en este estudio, pero redujo el rendimiento del maní.
\end{abstract}

Palmer amaranth is one of the most troublesome weeds for peanut production in the southeastern United States (Webster 2013). This weed is of major concern to growers due to its aggressive growth habit and high seed production. Recently, the evolution of herbicide resistance has made Palmer amaranth even more difficult to manage (Berger et al. 2015; Gaeddert et al. 1997; Sellers et al. 2003; Wise et al. 2009).

DOI: $10.1017 /$ wet. 2016.3

*First, second, third and fourth authors: Graduate Student, Professor, Graduate Student, and Graduate Student, Agronomy Department, P.O. Box 110500, Gainesville, FL 32611; Fifth author: Assistant Professor, West Florida Research and Education Center and Agronomy Department, University of Florida, Jay, FL 32565; Sixth author: Field Development Representative, UPI, Marianna, FL 32448. Corresponding author's E-mail: jferrell@ufl.edu 
A competitive species with high seed production, Palmer amaranth significantly affects peanut yields if not controlled early in the season. A single Palmer amaranth plant per meter of row has been shown to decrease peanut yields up to $28 \%$ (Burke et al. 2007).

For the past two decades, weed control in peanut has relied heavily on acetolactate synthase (ALS)inhibiting herbicides. The ALS-inhibiting herbicides have been attractive to growers because they offer advantages such as low use rates and effective control of a wide range of weed species while posing minimal risk for peanut injury (Bailey et al. 1999; Saari et al. 1994; Webster et al. 1997). However, these herbicides often possess extended residual activity, which increases the selection pressure for resistance (Saari et al. 1992). Consequently, 159 weed species are now resistant to ALS-inhibiting herbicides, more than are resistant to any other mode of action (Heap 2016). Palmer amaranth resistance to ALSinhibiting herbicides was first confirmed in Kansas in 1991, and later was discovered in Georgia and Florida in 2000 and 2008, respectively (Heap 2016; Horak and Peterson 1995). Surveys in these two states have shown that ALS-resistant Palmer amaranth has spread aggressively across peanut-growing regions. In Georgia, ALS-resistant Palmer amaranth has been confirmed in 21 peanut-growing counties (Wise et al. 2009), while $97 \%$ of the major agronomic counties in Florida and North Carolina also have confirmed resistance (Berger et al. 2015; Poirier et al. 2014).

Weeds resistant to ALS-inhibiting herbicides present a unique challenge to peanut production because few other POST herbicide options are available. One effective option is paraquat, but crop injury is severe and applications can only be made to peanuts up to $28 \mathrm{~d}$ after ground cracking (Anonymous 2016; Norsworthy et al. 2008). For mid-season application, the only other effective herbicides are the PPO-inhibitors. Palmer amaranth is adequately controlled by PPO-inhibiting herbicides when plants are less than $10 \mathrm{~cm}$ tall, but control declines quickly as plants surpass $10 \mathrm{~cm}$ in height (Gaeddert et al 1997; Grichar 2007, 2008; Grichar and Dotray 2011; Mayo et al. 1995; Morichetti et al. 2012). If applied when plants are taller than $10 \mathrm{~cm}$, most PPO-inhibiting herbicides control Palmer amaranth for 1 to 2 wk after treatment, but plants do not completely die and regrowth occurs (Morichetti et al. 2012). Sequential herbicide applications may be the solution to the problem of weed regrowth, because defoliating the plant a second time is likely to cause plant death or limit weed interference for an extended period of time. Sequential applications of lactofen have been shown to provide higher levels of control of common lambsquarters (Chenopodium album L.) than single applications (Jordan et al. 1993).

Regardless of the efficacy of PPO-inhibiting herbicides against Palmer amaranth, peanut injury is of concern, especially when applications are made late in the season (Boyer et al. 2011). Late POST application of acifluorfen plus bentazon and sequential applications of lactofen have caused reductions in peanut yield up to $49 \%$ and $45 \%$, respectively (Jordan et al. 1993). Applications of acifluorfen plus bentazon and lactofen have also been shown to cause severe reductions in peanut yield because applications are delayed to $4 \mathrm{wk}$ after cracking (Wilcut 1991). Conversely, Grichar (1997b) reported minor differences between the yields of peanuts treated with acifluorfen, bentazon, acifluorfen plus bentazon, and lactofen applied 7 to $41 \mathrm{~d}$ after planting. Another study investigated application timing of saflufenacil on peanut and found that despite foliar injury after applications (up to $34 \%$ ), saflufenacil could safely be applied up to $45 \mathrm{~d}$ after emergence and without reducing yield (>95\% of nontreated) (Morichetti et al. 2012). Similarly, lactofen applied 15,30, and $45 \mathrm{~d}$ after planting resulted in 29\%, 22\%, and $28 \%$ foliar injury $7 \mathrm{~d}$ after treatment, respectively, but yields were not reduced (Ferrell et al. 2013).

Though there are inconsistencies in the literature on PPO-inhibiting herbicide injury in peanut, higher levels of injury seem to occur when a pplications are later in the season. Also, much of the work that has been conducted using PPO-inhibiting herbicides in peanut has used single applications or sequential application spaced far apart ( $>2$ wk) (Boyer et al 2011; Dotray et al. 2012; Ferrell et al. 2013; Jordan et al. 1993). Therefore, the objective of this study was to evaluate the impact of sequential applications of PPO-inhibiting herbicides on the control of Palmer amaranth in peanut and the associated peanut injury and yield.

\section{Materials and Method}

Site and Materials. Field experiments were conducted in 2013 and 2014 at the University of Florida's Plant 
Science Research and Education Unit near Citra, FL. Soil for both experiments was Arredondo fine sand (loamy, siliceous, semiactive, hyperthermic Grossarenic Paleudult) with $<1 \%$ organic matter. Palmer amaranth control was investigated in a naturally infested fallow area with $>100$ Palmer amaranth seedlings $\mathrm{m}^{-2}$. In a separate experiment, herbicide treatments were applied to weed-free peanut to assess the impact of foliar injury on yield. All treatments were applied with a $\mathrm{CO}_{2}$ pressurized backpack sprayer calibrated to deliver $187 \mathrm{~L} \mathrm{ha}^{-1}$. Crop oil concentrate (Agri-Dex, Helena Chemical Co., Memphis, TN) was added to all herbicide treatments $(1 \% \mathrm{v} / \mathrm{v})$. Treatments were arranged as a two-factor factorial of herbicide and sequential application timing. A second application of each herbicide was made 5 or $15 \mathrm{~d}$ after the initial application (DAIT). Herbicide treatments comprised acifluorfen $\left(280 \mathrm{~g} \mathrm{ha}^{-1}\right)$ (Ultra Blazer, United Phosphorus Inc., King of Prussia, PA), acifluorfen $\left(280 \mathrm{~g} \mathrm{ha}^{-1}\right)$ plus bentazon $\left(560 \mathrm{~g} \mathrm{ha}^{-1}\right)$ (Storm, United Phosphorus Inc., King of Prussia, PA), acifluorfen $\left(280 \mathrm{~g} \mathrm{ha}^{-1}\right)$ plus bentazon $\left(560 \mathrm{~g} \mathrm{ha}^{-1}\right)$ plus 2,4-DB (280 $\left.\mathrm{g} \mathrm{ha}^{-1}\right)$ (Butyrac 200, Albaugh Inc., Ankeny, IA), and lactofen $\left(219 \mathrm{~g} \mathrm{ha}^{-1}\right)$ (Cobra, Valent U.S.A. Corporation, Walnut Creek, CA). Both experiments had randomized complete block designs with four replications.

Palmer Amaranth Control. A fallow field with a natural Palmer amaranth population was maintained to determine the efficacy of sequential PPO herbicide applications. Plots were 3.1 by $3.1 \mathrm{~m}$, and applications were made to the middle $1.8 \mathrm{~m}$ of each plot. Initial treatment applications were made June 13, 2013 and June 4, 2014. Palmer amaranth height averaged 10 to $20 \mathrm{~cm}$ and was at the 6 - to 12-leaf stage at the time of the initial application, and the herbicides were reapplied either 5 or 15 DAIT.

Peanut Response. Peanut 'Georgia-06G' (Branch 2007) was planted April 30, 2013 and April 29, 2014 in rows spaced $0.8 \mathrm{~m}$ apart. Four $7.6 \mathrm{~m}$ long rows were established as experimental units and herbicide applications were made across the entire plot. POST treatments were initiated $6 \mathrm{wk}$ after planting, at the R2 growth stage, on June 13, 2013 and June 11, 2014, followed by sequential herbicide applications either 5 or $15 \mathrm{~d}$ later (Boote 1982). Yield was determined from the center two rows of each plot to prevent an interaction from a border effect. Preemergence herbicides and hand weeding were used to maintain weed-free conditions throughout the duration of the experiment. Maturity and harvest timing were determined by the hull scrape method (Williams and Drexler 1981). After digging, peanuts were allowed to field dry for approximately $3 \mathrm{~d}$, and commercial harvesting equipment was used to determine yield (adjusted to 9\% moisture).

Data Collection and Analysis. Foliar peanut injury and Palmer amaranth control were estimated visually at $7,14,21$, and 28 DAIT using a scale of 0 to 100 (0 indicating no injury symptoms and 100 indicating plant death). Data analysis was conducted using the Agricolae package in R (version 0.98.1091, R Studio Inc., Boston, MA). Data were subjected to ANOVA to test significance of main effects and interactions. Where significant effects were detected, treatment means were compared using Fisher's protected LSD test $(\alpha=0.05)$.

\section{Results and Discussion}

Palmer Amaranth. There were no interactions between year and main effects of herbicide or sequential application interval $(p=0.55)$ in the Palmer amaranth control study. Therefore, data were pooled across years. However, an interaction was detected between the main effects of herbicide and sequential application interval for Palmer amaranth control 7, 14, 21, and 28 DAIT $(p<0.05)$.

At the 7 and 14 DAIT evaluation dates, the $15 \mathrm{~d}$ sequential application had not yet been applied. Therefore, the 7 and 14 DAIT data for the $15 \mathrm{~d}$ interval treatments reflect the response to a single application (Table 1). At 7 DAIT, the $5 \mathrm{~d}$ interval provided greater control of Palmer amaranth than the single application $(15 \mathrm{~d})$ in all herbicides except lactofen. By 14 DAIT, herbicides applied at the $5 \mathrm{~d}$ interval provided better control of Palmer amaranth than a single application (15d) for all herbicides tested. With the exception of lactofen at 7 DAIT, the 7 and 14 DAIT data showed that two applications of all herbicides controlled Palmer amaranth better than a single application.

At 7 DAIT, the single application of lactofen $(15 \mathrm{~d}$ interval treatment) provided the same level of control as lactofen applied twice ( $5 \mathrm{~d}$ interval treatment). Also, the single application of lactofen ( $15 \mathrm{~d}$ interval treatment) controlled Palmer amaranth as effectively or better than all other herbicides tested, regardless 
Table 1. Influence of the interaction between herbicide and sequential application interval on Palmer amaranth control. Palmer amaranth control was evaluated on a scale from $0 \%$, representing no control, to $100 \%$, representing complete control.

\begin{tabular}{|c|c|c|c|c|c|}
\hline Herbicide & $\begin{array}{l}\text { Sequential application } \\
\text { interval }^{\mathrm{b}} \text { (d) }\end{array}$ & \multicolumn{4}{|c|}{ Palmer amaranth control } \\
\hline & & & & & \\
\hline Acifluorfen & 5 & $76 \mathrm{a}^{\mathrm{a}}$ & $69 \mathrm{bc}$ & $51 \mathrm{de}$ & $34 \mathrm{c}$ \\
\hline Acifluorfen & 15 & $50 \mathrm{~b}$ & $27 \mathrm{e}$ & $73 \mathrm{bc}$ & $57 \mathrm{~b}$ \\
\hline Acifluorfen plus bentazon & 5 & $55 \mathrm{~b}$ & $51 \mathrm{~d}$ & $40 \mathrm{e}$ & $32 \mathrm{c}$ \\
\hline Acifluorfen plus bentazon plus 2,4-DB & 15 & $61 \mathrm{~b}$ & $52 \mathrm{~cd}$ & $84 \mathrm{~b}$ & $65 \mathrm{~b}$ \\
\hline Lactofen & 5 & $88 \mathrm{a}$ & $86 \mathrm{a}$ & $66 \mathrm{~cd}$ & $55 \mathrm{~b}$ \\
\hline Lactofen & 15 & $89 \mathrm{a}$ & $63 \mathrm{bd}$ & $100 \mathrm{a}$ & $94 \mathrm{a}$ \\
\hline
\end{tabular}

of the number of applications, when evaluated at 7 DAIT. This indicates that Palmer amaranth may not be able to recover as quickly from lactofen as from the other herbicides tested. Also, the lactofen product label requires that sequential applications be made at least 14 DAIT, possibly because the level of control does not improve when applied at a shorter interval (Anonymous 2015). Although studies have shown lactofen to have higher activity on Palmer amaranth than acifluorfen, bentazon, or 2,4-DB, many of these studies did not investigate the recovery of Palmer amaranth over time (Grichar 1997a, 2008; Mayo et al. 1995). Gaeddert et al (1997) did record Palmer amaranth control over time and found that acifluorfen and lactofen provided the same level of control $7 \mathrm{~d}$ after treatment, but by $28 \mathrm{~d}$ after treatment lactofen provided $16 \%$ more control than acifluorfen.

At 21 DAIT, sequential application at a $15 \mathrm{~d}$ interval provided more control than sequential application at a $5 \mathrm{~d}$ interval for all herbicide programs tested except acifluorfen plus bentazon. Lactofen reapplied at a $15 \mathrm{~d}$ interval provided $100 \%$ control of Palmer amaranth by 21 DAIT, the highest rating seen in any treatment (Table 1). Palmer amaranth plants had recovered from initial applications by the $15 \mathrm{~d}$ application and had resprouted to approximately $7 \mathrm{~cm}$ total plant height. Lactofen has been shown to be more active on larger Palmer amaranth plants than acifluorfen (Mayo et al. 1995).

At 28 DAIT, there was no difference in control of Palmer amaranth between sequential application intervals of acifluorfen plus bentazon or acifluorfen plus bentazon plus 2,4-DB. The addition of 2,4-DB to acifluorfen plus bentazon resulted in approximately 30\% more control of Palmer amaranth compared to acifluorfen plus bentazon alone (Table 1). Acifluorfen reapplied at a $15 \mathrm{~d}$ interval provided 22\% more control of Palmer amaranth at 28 DAIT than acifluorfen reapplied at a $5 \mathrm{~d}$ interval. By 28 DAIT, lactofen reapplied 15 DAIT provided 94\% control of Palmer amaranth, the only treatment that controlled Palmer amaranth $>65 \%$ at the final evaluation time. High levels of Palmer amaranth control have also been observed in previous research with acifluorfen and lactofen $(96 \%$ and $100 \%$ respectively) (Grichar 2008). Overall, lactofen reapplied at a $15 \mathrm{~d}$ interval was the most successful treatment in controlling Palmer amaranth over the 4 -wk evaluation period, despite control dropping to $63 \% 14$ DAIT. While many growers consider $<85 \%$ weed control to be failure, lactofen reapplied at a $15 \mathrm{~d}$ interval was the only treatment that provided this level of control at 3 out of the 4 evaluation dates. Furthermore, it is important to keep in mind that this study was conducted under a crop-free scenario. It is likely that Palmer amaranth control will be better in the presence of a peanut canopy, which might decrease Palmer amaranth recovery from the herbicide programs evaluated.

The reason why lactofen was more effective when reapplied at a $15 \mathrm{~d}$ interval compared to a $5 \mathrm{~d}$ interval may be that the amount of available leaf area was larger 15 DAIT than it was 5 DAIT. At the $5 \mathrm{~d}$ 
Table 2. Influence of the interaction between herbicide and sequential application interval on peanut foliar injury and yield, expressed as percent of nontreated control. Peanut foliar injury was evaluated on a scale from $0 \%$, representing no injury, to $100 \%$, representing plant death.

\begin{tabular}{|c|c|c|c|c|c|c|}
\hline \multirow[b]{2}{*}{ Herbicide } & \multirow{2}{*}{$\begin{array}{l}\text { Sequential application } \\
\text { interval }^{\mathrm{b}} \text { (d) }\end{array}$} & \multicolumn{5}{|c|}{ Peanut injury } \\
\hline & & $7 \mathrm{DAIT}^{\mathrm{c}}$ & 14 DAIT & 21 DAIT & 28 DAIT & Yield $^{\mathrm{d}}$ \\
\hline Acifluorfen & 5 & $23 \mathrm{~d}^{\mathrm{a}}$ & $10 \mathrm{~b}$ & $6 a$ & $0 \mathrm{a}$ & $89 \mathrm{ab}$ \\
\hline Acifluorfen & 15 & $13 \mathrm{ab}$ & $5 \mathrm{ab}$ & $14 \mathrm{~b}$ & $0 \mathrm{a}$ & $92 \mathrm{ab}$ \\
\hline Acifluorfen plus bentazon & 5 & $16 \mathrm{bc}$ & $7 \mathrm{ab}$ & 5 a & $0 \mathrm{a}$ & $87 \mathrm{ab}$ \\
\hline Acifluorfen plus bentazon plus 2,4-DB & 15 & $11 \mathrm{a}$ & $4 \mathrm{a}$ & $10 \mathrm{ab}$ & $0 \mathrm{a}$ & $91 \mathrm{ab}$ \\
\hline Lactofen & 5 & $41 \mathrm{e}$ & $21 \mathrm{c}$ & $12 \mathrm{~b}$ & $3 \mathrm{~b}$ & $81 \mathrm{bc}$ \\
\hline Lactofen & 15 & 38 e & $20 \mathrm{c}$ & $34 \mathrm{~d}$ & $15 \mathrm{c}$ & $74 \mathrm{c}$ \\
\hline
\end{tabular}

interval, much of the leaf area that was left on the plant was necrotic, thus reducing absorption of the second herbicide application. Due to the contact activity of these herbicides, more green leaf area allows for more coverage, and thus more control (Berger et al. 2014).

Peanut Response. There were no interactions between year and main effects of herbicide or sequential application interval in the peanut response study $(p=0.31)$. Therefore, data were pooled across years. With the exception of acilluorfen reapplied at a $5 \mathrm{~d}$ interval and both lactofen treatments, peanut injury was $<20 \% 7$ DAIT (Table 2). Acifluorfen and acifluorfen plus bentazon plus 2,4-DB, reapplied at a $5 \mathrm{~d}$ interval, caused $10 \%$ and $7 \%$ more peanut injury at 7 DAIT, respectively, than the single application $(15 \mathrm{~d}$ interval treatment). No difference in peanut injury between application intervals was observed at 7 DAIT for acifluorfen plus bentazon or lactofen treatments. Both lactofen treatments caused the highest peanut injury 7 DAIT, resulting in approximately $40 \%$ injury. By 14 DAIT, peanut had recovered from the initial application and the $5 \mathrm{~d}$ interval application in all treatments (injury $<11 \%$ ) except for lactofen at both application intervals, which maintained greater than $20 \%$ injury. Also, at 14 DAIT, no statistical difference was detected between the application intervals of any herbicide. This is particularly interesting because at 14 DAIT the $15 \mathrm{~d}$ interval treatments had not yet been applied, thus the data compare two applications made $5 \mathrm{~d}$ apart to a single application. While there were differences in Palmer amaranth control between application intervals at 14 DAIT, the $5 \mathrm{~d}$ interval reapplication controlled Palmer amaranth more effectively than the $15 \mathrm{~d}$ interval reapplication, without causing increased peanut injury. Although this may be an acceptable application interval for minimizing peanut injury, it will only afford maximized Palmer amaranth control for a short period compared to reapplying at a $15 \mathrm{~d}$ interval. At the time the $5 \mathrm{~d}$ applications were made, the leaves may have become necrotic, limiting peanut absorption of the 5 DAIT herbicide application.

Injury caused by acifluorfen applied at a $15 \mathrm{~d}$ interval did not exceed 14\% at any data collection time. Conversely, foliar peanut injury from acifluorfen reapplied at a $5 \mathrm{~d}$ interval resulted in $23 \%$ injury 7 DAIT (Table 2). Overall, peanut injury was the same or lower when acifluorfen was reapplied at a $15 \mathrm{~d}$ interval rather than at a $5 \mathrm{~d}$ interval, and provided higher Palmer amaranth control at 21 and 28 DAIT (Table 1).

At 21 DAIT, the $15 \mathrm{~d}$ interval application was more injurious to peanut than the $5 \mathrm{~d}$ interval application timing in all herbicides except acifluorfen plus bentazon plus 2,4-DB (Table 2). Peanut has been shown to be extremely tolerant to applications of 2,4-DB (Baughman et al. 2002; Faircloth and Prostko 
2010; Ferrell et al. 2013). Surprisingly, 10\% less injury was observed 21 DAIT from 2,4-DB plus acifluorfen plus bentazon reapplied at a $15 \mathrm{~d}$ interval compared to acifluorfen plus bentazon alone reapplied at a $15 \mathrm{~d}$ interval. Although at 21 DAIT applications of acifluorfen and acifluorfen plus bentazon caused greater injury when reapplied at a $15 \mathrm{~d}$ interval rather than at a $5 \mathrm{~d}$ interval, no peanut injury was present at 28 DAIT for any treatment except both lactofen applications. Lactofen reapplied at 5 and $15 \mathrm{~d}$ intervals caused $3 \%$ and $15 \%$ peanut injury, respectively.

Peanut injury 28 DAIT from lactofen reapplied at 5 and $15 \mathrm{~d}$ intervals resulted in the lowest yields $(81 \%$ and $74 \%$ of nontreated control, respectively) (Table 2). Peanut yield did not differ significantly in any of the treatments that contained acifluorfen, ranging from $87 \%$ to $93 \%$ of the nontreated control. Similarly, a study comparing single applications of acifluorfen, acifluorfen plus bentazon, and lactofen applied POST to peanut showed no differences in yield between treatments (Grichar 1997b). However, in the present study, lactofen reapplied at 5 and $15 \mathrm{~d}$ intervals caused reductions in peanut yield of $19 \%$ and 26\%, respectively (Table 2). Sequential applications of lactofen applied early POST and late POST have been shown to reduce peanut yields $45 \%$ (Jordan et al. 1993). Also, Wilcut (1991) observed much more severe reductions in yield from acifluorfen plus bentazon and lactofen when applied $4 \mathrm{wk}$ after cracking $(39 \%$ and $45 \%$, respectively). Similar responses of peanut to sequential applications of lactofen applied $2 \mathrm{wk}$ apart have been observed, with yield reductions ranging from $17 \%$ to $19 \%$ (Wilcut et al. 1990). While lactofen reapplied at a $15 \mathrm{~d}$ interval caused the greatest reduction in peanut yield, it also provided the highest level of Palmer amaranth control 21 and 28 DAIT. Dotray et al. (2012) concluded, after studies involving sequential applications of lactofen in peanut, that although foliar injury might occur, yield reductions are uncommon if all applications are made before full seed fill. This assertion is also printed on the product label (Anonymous 2015). Boyer et al (2011) found that lactofen caused $9 \%$ and $17 \%$ reductions in peanut yield when applied 8 or $10 \mathrm{wk}$ after planting, respectively, despite observed foliar injury of up to $48 \%$.

In summary, sequential applications of PPO herbicides can be an effective means for controlling Palmer amaranth. Peanut tolerance to these herbicides is sufficient to allow this practice. However, care must be taken if sequential applications of lactofen are to be made in a mid-season timeframe. Unfortunately, PPO-resistant Palmer amaranth has been discovered (Heap 2016), and following these recommendations could increase selection pressure on Palmer amaranth to develop resistance to this herbicide class.

\section{Literature Cited}

Anonymous (2015) Cobra herbicide product label. Valent Publication No. 2015-COB-0001. Walnut Creek, CA: Valent U.S.A. Corporation. $16 \mathrm{p}$

Anonymous (2016) Gramoxone SL 2.0 herbicide product label. Syngenta Publication No. SCP 1431A-L1E 11154060665. Greensboro, NC: Syngenta Crop Protection, LLC. 55 p

Bailey WA, Wilcut JW, Jordan DL, Swann CW, Langston VB (1999) Weed management in peanut (Arachis hypogaea) with diclosulam preemergence. Weed Technol 13:450-456

Baughman TA, Grichar WJ, Jordan DL (2002) Tolerance of Virginia-type peanut to different application timings of 2,4-DB. Peanut Sci 29:126-128

Berger ST, Dobrow MH, Ferrell JA, Webster TM (2014) Influence of carrier volume and nozzle selection on palmer amaranth control. Peanut Sci 41:120-123

Berger ST, Ferrell JA, Dittmar PJ, Leon R (2015) Survey of glyphosate- and imazapic-resistant palmer amaranth (Amaranthus palmeri) in Florida. Crop, Forage \& Turfgrass Manag. doi: 1:10.2134/cftm2015.0122

Boote KJ (1982) Growth stages of peanut (Arachis hypogaea L.). Peanut Sci 9:35-40

Boyer JA, Ferrell J, MacDonald G, Tillman B, Rowland D (2011) Effect of acifluorfen and lactofen application timing on peanut injury and yield. Crop Manag. doi: 10:10.1094/CM-20110519-01-RS

Branch WD (2007) Registration of 'Georgia-06G' peanut. J. Plant Registration 1:120

Burke IC, Schroeder M, Thomas WE, Wilcut JW (2007) Palmer amaranth interference and seed production in peanut. Weed Technol 21:367-371

Dotray PA, Grichar WJ, Baughman TA, Prostko EP, Grey TL, Gilbert LV (2012) Peanut (Arachis hypogaea L.) response to lactofen at various postemergence timings. Peanut Sci 39:9-14

Faircloth WJ, Prostko EP (2010) Effect of imazapic and 2,4-DB on peanut yield, grade and seed germination. Peanut Sci 37:78-82

Ferrell JA, Leon RG, Sellers B, Rowland D, Brecke B (2013) Influence of lactofen and 2,4-DB combinations on peanut injury and yield. Peanut Sci 40:62-65

Gaeddert JW, Peterson DE, Horak MJ (1997) Control and cross-resistance of an acetolactate synthase inhibitor-resistant palmer amaranth (Amaranthus palmeri) biotype. Weed Technol 11:132-137

Grichar WJ (1997a) Control of Palmer amaranth (Amaranthus palmeri) in peanut (Arachis hypogaea) with postemergence herbicides. Weed Technol 11:739-743 
Grichar WJ (1997b) Influence of herbicides and timing of application on broadleaf weed control in peanut (Arachis hypogaea). Weed Technol 11:708-713

Grichar WJ (2007) Horse purslane (Trianthem portulacastrum), smellmelon (Cucumis melo), and Palmer amaranth (Amaranthus palmeri) control in peanut with postemergence herbicides. Weed Technol 21:688-691

Grichar WJ (2008) Herbicide systems for control of horse purslane (Trianthema portulacastrum L.), smellmelon (Cucumis melo L.), and Palmer amaranth (Amaranthus palmeri S. Wats) in peanut. Peanut Sci 35:38-42

Grichar WJ, Dotray PA (2011) Controlling weeds found in peanut with lactofen. Crop Manag. doi: 10.1094/CM-20110912-01-RS

Heap I (2016) The International Survey of Herbicide Resistant Weeds. www.weedscience.org. Accessed October 15, 2014

Horak MJ, Peterson DE (1995) Biotypes of Palmer amaranth (Amaranthus palmeri) and common waterhemp (Amaranthus rudis) are resistant to imazethapyr and thifensulfuron. Weed Technol 9:192-195

Jordan DL, Wilcut JW, Swann CW (1993) Application timing of lactofen for broadleaf weed control in peanut (Arachis hypogaea). Peanut Sci 20:129-131

Mayo CM, Horak MJ, Peterson DE, Boyer JE (1995) Differential control of four Amaranthus species by six postemergence herbicides in soybean (Glycine max). Weed Technol 9:141-147

Morichetti S, Ferrell J, MacDonald G, Sellers B, Rowland D (2012) Weed management and peanut response from applications of saflufenacil. Weed Technol 26:261-266

Poirier AH, York AC, Jordan DL, Chandi A, Everman WJ, Whitaker JR (2014) Distribution of glyphosate- and thifensulfuronresistant Palmer amaranth (Amaranthus palmeri) in North Carolina. Int J Agr. doi: 10.1155/2014/747810

Saari LL, Cotterman JC, Smith WF, Primiani MM (1992) Sulfonylurea herbicide resistance in common chickweed, perennial ryegrass and Russian thistle. Pest Biochem Physiol 42:110-118

Saari LL, Cotterman JC, Thill DC (1994) Resistance to acetolactate synthase-inhibiting herbicides. Pages 83-139 in Powles SB \& Holtum J eds. Herbicide Resistance in Plants: Biology and Biochemistry. Chelsea, MI: Lewis Press

Sellers BA, Smeda RJ, Johnson WG, Kendig JA, Ellersieck MR (2003) Comparative growth of six Amaranthus species in Missouri. Weed Sci 51:329-333

Webster TM (2013) Weed survey - southern states: broadleaf crops sub-section. Pages 275-287 in Proceedings of the Southern Weed Science Society $66^{\text {th }}$ Annual Meeting. Houston, TX: Southern Weed Science Society

Webster TM, Wilcut JW, Coble HD (1997) Influence of AC 263,222 rate and application method on weed management in peanut (Arachis hypogaea). Weed Technol 11:520-526

Wehtje G, Wilcut JW, McGuire JA (1992) Influence of bentazon on the phytotoxicity of paraquat to peanuts (Arachis hypogaea) and associated weeds. Weed Sci 40:90-95

Wilcut JW (1991) Economic yield response of peanut (Arachis hypogaea) to postemergence herbicides. Weed Technol 5: 416-420

Wilcut JW, Swann CW (1990) Timing of paraquat applications for weed control in Virginia-type peanuts (Arachis hypogaea). Weed Sci 38:558-562

Wilcut JW, Swann CW, Hagwood HB (1990) Lactofen systems for broadleaf weed control in peanuts (Arachis hypogaea). Weed Technol 4:819-823

Williams EJ, Drexler JS (1981) A non-destructive method for determining peanut pod maturity. Peanut Sci 8: 134-141

Wise AM, Grey TL, Prostko EP, Vencill WK, Webster TM (2009) Establishing the geographical distribution and level of acetolactate synthase resistance of Palmer amaranth (Amaranthus palmeri) accessions in Georgia. Weed Technol 23:214-220

Received August 11, 2016, and approved October 21, 2016.

Associate Editor for this paper: Jason Bond, Mississippi State University. 